\title{
A comparison of retirement saving using discretionary investment and Regulation 28
}

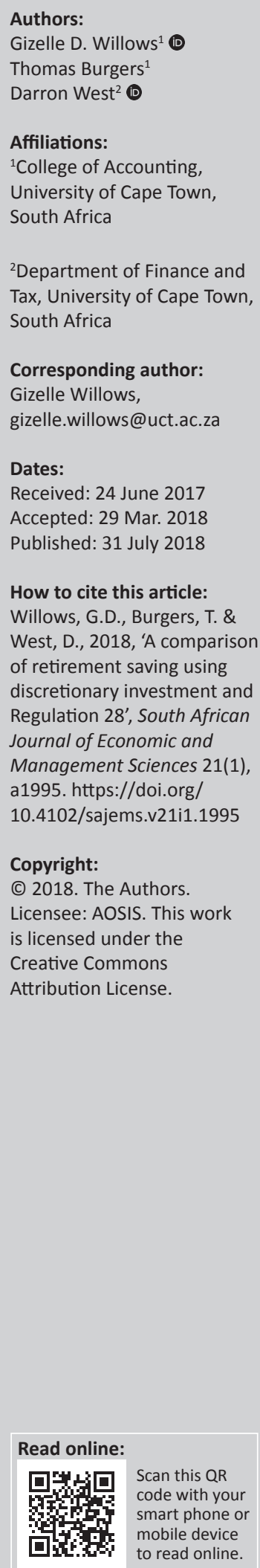

Background: There is growing uncertainty in global society with regard to how retirement savings should be approached. The primary reason for this is that most societies do not save enough and their citizens run out of money during retirement.

Aim: This study investigates whether the limitations imposed by Regulation 28 of the Pension Funds Act of South Africa encourage optimal asset allocation and reduce investment risk for retirement savings when contrasted with discretionary investment.

Setting: The study looks at hypothetical individuals who are subject to tax and retirement consequences as administered by South African legislation.

Methods: A quantitative risk and return analysis was performed while considering two hypothetical investors who are identical in all aspects other than their choice of investments.

Results: The findings indicate that Regulation 28 is effective in reducing the investment risk of retirement savings; however, it may also force the investor to sacrifice wealth.

Conclusion: Depending on the tax bracket in which the investor sits, discretionary investment may be preferential to investing in a retirement fund under the mandate of Regulation 28.

\section{Introduction}

Saving for retirement is an area that has been thoroughly researched in recent periods (Behrman et al. 2012; Benartzi \& Thaler 2013). The primary reason for this is that most societies do not save enough and their citizens run out of money during retirement (Skinner 2007). This has caused growing uncertainty in global society with regard to how retirement savings should be approached.

In the South African context, there is limited research on retirement saving. The current proposed method for retirement saving is to invest in a pension, provident or retirement annuity fund. These funds are regulated investment vehicles which have specific rules governed by Regulation 28 of the Pension Funds Act (No. 24 of 1956). Regulation 28 imposes limitations on the investments of such funds, that is, it limits investment in more risky assets and asset classes, with the aim to protect individuals' earnings and ensure that their savings are invested in a properly diversified portfolio. A non-Regulation 28 product will not have any of these limitations imbedded in it. The goal of this research is to determine whether or not the current proposals to invest in Regulation 28 retirement funds are indeed the best option.

The research is novel as it determines a quantifiable excess return required from discretionary investment in order to make discretionary investment the preferred choice for retirement saving. The research also adds practical value to investment houses who offer both Regulation 28 compliant products and non-Regulation 28 compliant products.

\section{Literature review}

Individual preferences may dictate the manner in which individuals choose to save for retirement. Previous studies have focused on how individuals should save for retirement (Pfau 2010) and contrasted these with empirical evidence. To date, no literature exists that indicates whether the incentives provided in South African taxation legislation coupled with regulation for retirement savings vehicles make sense from an economic and risk perspective. The purpose of this study is

Note: This article is partially based on the second author's dissertation for the degree of Master of Commerce specialising in Finance (in the field of Financial Management) at the University of Cape Town, South Africa, with supervisors Gizelle Willows and Darron West, received January 2016, available here: http://open.uct.ac.za/bitstream/handle/11427/20507/thesis_com_2016\%20_burgers_thomas. pdf?sequence $=1$ 
to determine whether these economic incentives provided in tax legislation encourage effective retirement saving. To do this it is necessary to present an illustration of the global understanding of the retirement saving puzzle while considering the South African regulatory environment and incentive structure.

This literature review will begin by giving an overview of the South African regulatory framework surrounding retirement savings, with a specific focus on Regulation 28 and its limitations based on academic research on asset allocation. Following that, the relevant literature on savings, beginning with the Keynesian consumption function (Keynes 1936), will be reviewed. Thereafter, behavioural biases present in retirement saving will be considered.

\section{Pension fund regulation in South Africa}

Pension, provident and retirement annuity funds in South Africa are governed by legislation, namely the Pensions Funds Act as well as the regulations that are applicable to said Act. In South Africa, there are three predominant savings vehicles for retirement savings: pension funds, provident funds and retirement annuity funds. These funds operate with the main objective to accumulate savings during one's career in order to maintain one's lifestyle after retirement, and all operate in a similar manner. The promulgation of the Taxation Laws Amendment Act (No. 31 of 2013), which became effective 01 March 2015, permits all contributions to pension, provident and retirement annuity funds to be tax deductible, and will impose capital withdrawal limits on all three funds. This is explained later in the article.

Of particular relevance to this research is the amendment to Regulation 28 of the regulations made under section 36 of the Pensions Fund Act. Regulation 28 imposes limits on the investments of retirement funds; the purpose of these limits is to protect the funds from making imprudent investments (National Treasury 2011). The limits prescribe the maximum percentage of the fund assets that can be invested in any particular asset class, as well as per issuer or entity within that asset class. The effect is that these limits enforce diversification, and as a result are supposed to protect investors from poor investment decision and asset allocation.

Regulation 28 prescribes certain maxima per investment type based on the fair value of assets under management. The maxima are as follows (National Treasury 2011):

- No more than $10 \%$ of total assets may be invested in hedge funds.

- No more than $10 \%$ of total assets may be invested in private equity funds.

- No more than $10 \%$ may be invested in unlisted companies.

- No more than $10 \%$ may be invested in any single listed company with a market capitalisation of between R2 billion and R20 billion.

- No more than $30 \%$ of South African liabilities plus $100 \%$ of foreign liabilities may be invested in foreign equity.
The Income Tax Act (No. 58 of 1962) provides tax benefits as it legislates that taxpayers may deduct any contributions to pension funds, provident funds and retirement annuity funds $(\mathrm{s} 11[\mathrm{k}])$, subject to certain limits, from their income in the determination of taxable income, resulting in a lower tax liability. These funds are the same funds that are subject to the Pension Funds Act. The benefits are as follows:

- Contributions to pension funds are limited to the lesser of R350 000 or $27.5 \%$ of the greater of remuneration as defined or income in the determination of taxable income - s11(k).

- Withdrawals from these funds are taxed in terms of the Second Schedule of the Income Tax Act. The result is a lower effective tax rate than if the funds were to constitute normal income.

These benefits are meant to provide an incentive to save for retirement; but the incentive is only provided if saving takes place in a fund that is subject to the constraints imposed by Regulation 28 ('Regulation 28 compliant'). The manner in which these incentives work is to moderately increase the size of the initial investment as a result of the tax relief (Attanasio \& Banks 2004).

When comparing retirement regulation in South Africa to other countries, differences are apparent. In the US, the 401(k) is the major retirement scheme used by employees. Employees contribute to the plans either by electing 'Roth' contributions (which are made after-tax by retirement withdrawals and are tax free), or pre-tax contributions (which reduce their taxable income by retirement withdrawals and are taxed; Fidelity Investments 2017). A unique feature of the $401(\mathrm{k})$ is the potential for a vesting schedule related to the employer's contributions whereby an employee may not be fully entitled to them until after a particular period of employment (Internal Revenue Service 2017). The 401(k) scheme has an automatic enrolment feature where employers can automatically enrol employees to increase participation. This scheme is different from the Australian scheme which enforces employer contributions.

Australia utilises superannuation as its major retirement scheme, where employees and employers contribute to a superfund which invests the funds on their behalf. Employers must contribute at least $9.5 \%$ of the employee's earnings regardless of their type of employment but subject to exceptions (Australian Taxation Office 2017). Types of contributions are taxed differently. Before tax (concessional) contributions are taxed at $15 \%$ which include employer contributions and contributions allowed as income tax deductions. After-tax (non-concessional) contributions are not subject to tax and include contributions made from after-tax income (Australian Taxation Office 2017).

Given the differences in retirement schemes globally, further research is required to determine which combination of regulations is in the best interest of both the employer and employee. For this article, specific focus is placed on 
Regulation 28 legislation in South Africa, to isolate its effectiveness in maximising retirement wealth.

\section{Asset allocation, volatility and offshore exposure}

The above section explains Regulation 28, and its limitations. This section will address the two major weaknesses of Regulation 28: asset allocation and offshore exposure.

In saving for retirement, the optimal asset allocation is person specific, as it needs to consider labour income levels, and the risk of change to labour income (human capital risk). Labour income is the income individuals are able to earn by employing their human capital. The presence of labour income allows an individual to have an age-varying investment strategy (Cocco, Gomes \& Maenhout 2005). This means that the investment can be changed over the course of one's life, to allocate assets to suit one's risk profile at a given point in time.

Upon investment in a Regulation 28 fund, individuals cede the responsibility of their own asset allocation in retirement savings to that of a fund manager, within the Regulation 28 mandated limits. Wepener (2014) finds that the limits of Regulation 28 do not encourage optimal asset allocation in a portfolio.

Equity has been shown to be more volatile than debt instruments (Mehra 2003). In South Africa specifically, over a period of 90 years from 1925, equity has earned a real return of $8.4 \%$ per year (Luüs 2015). Compared to the $1.6 \%$ earned by bonds and $0.9 \%$ by cash instruments over the same period (Luüs 2015), the additional premium that can be earned from equity exposure is clear. Considering the holding period of a Regulation 28 fund, where members join at the beginning of their working career and withdraw upon retirement, Mehra (2003) advocates a case for greater equity exposure. While this momentum in South African equity returns cannot necessarily be retained in the future, it has outdone countries such as the US, the UK, Japan and Germany (Donnelly 2017). More recently, between 2000 and 2016, local South African equity performed even better, earning a real return of $8.2 \%$ (Dimson et al. 2017).

Similarly, Wachter (2010) finds that as the length of the investment horizon increases, so should the allocation to equities, yet Regulation 28 retirement funds - which operate as long-term investment vehicles for their members - are restricted from maintaining equity exposure of more than $75 \%$. Wachter's (2010) finding is supported by the findings of Blanchett, Finke and Pfau (2013), who find that long-term investors should hold proportionately more equity than short-term investors.

Furthermore, there are restrictions placed on foreign investments. While the benefits of international diversification are widely accepted (Ratner \& Leal 2005), most investors hold most of their wealth in domestic assets, a phenomenon known as home bias. Despite the proven benefits of diversification, both historically and more recently, Regulation 28 still imposes limits on fund exposure to foreign investments.

With these restrictions in mind, the economic environment following certain market events has changed the fundamentals for regulation. Much of the volatility that emerged from moments of market crisis have been unprecedented. These potentially influenced regulators to solidify laws such as Regulation 28 to ensure pensioners' savings were preserved. In particular, the 2008 financial crisis negatively impacted retirement security (Miller 2011) which, in turn, influenced regulators to uphold tighter and more conservative retirement laws. ${ }^{1}$

\section{Theories of saving}

In order to address the issue of saving for retirement, it is necessary to discuss the major theories of saving. Under this section the original savings and consumption function (Keynes 1936) will be contrasted with the life-cycle hypothesis (Modigliani \& Brumberg 1954), and the permanent income hypothesis (Friedman 1957). These theories have arisen out of contentions on how individuals allocate their resources between saving and consumption, with each theory having its own merits and pitfalls.

The original savings and consumption function was proposed by Keynes (Keynes 1936): a theory where households' consumption was driven by real income, but an increase in real income would not result in the same increase in consumption (Keynes 1936). This is known as the Keynesian consumption function.

Modigliani and Brumberg (1954) then proposed the life-cycle hypothesis of saving. Under this theory, consumers were assumed to be rational, utility-maximising beings, and would, therefore, allocate their resources in order to achieve an optimal consumption pattern over the course of their life, which can be divided into several stages. This model thus asserts that the individual is aware of a lifetime budget constraint, and will use assets as a tool to shift consumption from one stage to another (Bodie, Treussard \& Willen 2007).

If the Keynesian consumption function were adopted, rather than the life-cycle theory, as wealth increased the value of savings would increase due to an increasing propensity to save, whereas under life-cycle theory, the individuals would adjust their forward-looking consumption and savings functions to account for this change.

The savings behaviour predicted by the life-cycle theory can be contrasted with the permanent income hypothesis (Friedman 1957). Under the permanent income hypothesis theory, consumption is a function of permanent income (anticipated income) and thus saving is a residual. This is to 1.Thank you to an anonymous reviewer for this commentary. 
say that any short-term ('transitory') changes in income are unlikely to result in large changes in consumption, but rather additions to assets.

While all of these theories provide some degree of explanation as to how individuals save for retirement, none of the theories appears to be able to explain all factors. The preceding hypotheses all ignore important elements of human behaviour in the sense that they assume that human beings will always act rationally. Therefore it is not possible to conclude that any one of these theories is entirely valid. For the purposes of this article, it is accepted that the method individuals use to accumulate capital is in line with the lifecycle hypothesis on the basis that recent empirical evidence has shown retirement fund asset allocation to be consistent with this hypothesis (Bikker et al. 2012) although there are inherent limitations, which are discussed in the next section.

\section{Human behaviour}

While the aforementioned theories of saving are relevant for understanding the economics involved in savings choices, they ignore elements of human behaviour. It is, therefore, necessary to obtain an understanding of the behavioural factors that influence how individuals save. This section will discuss issues regarding self-control (Thaler \& Benartzi 2007), poor financial education (Klapper, Lusardi \& Van Oudheusen 2015) and risk aversion (Bodie et al. 2007), all of which are likely to influence savings behaviour in some manner.

\section{Self-control}

Saving for retirement requires a degree of rationality and self-control. This asserts that households are forward looking and are able to plan adequately over both the short term and the long term.

Knoll et al. (2010) describe how individuals behave too myopically to adequately view their long-term savings. This is supported by Somaguda-Nogantshi (2008) who found poor South Africans discounting future needs for current needs. Individuals often fail to save enough for retirement, as this would require that their present standard of living be reduced in order to have a better standard of living at a later stage (Fernández-Villaverde \& Krueger 2011).

Lusardi and Mitchell (2014) further propose that very few consumers are capable of computing the complex financial calculations. To overcome the inability to calculate the amount of saving that is necessary, most people use heuristics or rules of thumb (Thaler \& Benartzi 2007). Thaler and Benartzi (2007) recognise that self-control is an aspect that is difficult for individuals to deal with, and thus these consumers will often resort to using pension plans in order to force their own self-control. Individuals will use a form of mental accounting (Van Zyl \& Van Zyl 2014) and categorise money into current spendable income, current assets and future income.

\section{Financial education}

Klapper et al. (2015) suggest that many individuals lack the financial knowledge to make appropriate use of the financial products available to them. Previously, institutional investors have been largely responsible for financial planning advice; however, it appears there has been a shift with households beginning to take a more active role and more responsibility for their retirement saving (Bodie et al. 2007). A common problem that Bodie and Treussard (2007) point out is that, on average, an individual saving for retirement is not well educated in the field of finance and thus has a poor understanding of asset allocation, which would result in them making poor decisions. This was confirmed by Willows (2015) who found that lower self-assessed levels of financial knowledge were negatively correlated to participation in collective investment schemes, in particular those with heightened equity exposure.

Historically, retirement funds in South Africa were defined benefit plans (DBPs), where employers contributed to a pension fund on behalf of their employees and such employees were guaranteed a pension upon retirement. When these DBPs were replaced with defined contribution funds in the early 1990s in South Africa, the responsibility for saving was shifted to the employee. This resulted in employees being exposed to different risks that they needed to manage, such as investment risk. Given the limited financial knowledge of individuals (Klapper et al. 2015), the ability to effectively manage these risks is questionable. This emphasises the importance of ensuring appropriate taxation legislation to assist individuals.

\section{Risk aversion}

Risk aversion, applied to a retirement saving context, would be investing in a low-risk low-yield asset class at an early stage in one's career when they should rather be investing in a higher yielding asset class. Retirement saving behaviour is driven by risk tolerance; an individual with low job security has high human capital risk and thus reduces overall risk by choosing low-risk financial assets. Bodie and Treussard (2007) describe human capital as the ability to earn income by utilising the skill set the individual has acquired.

Building on risk aversion, it is suggested that as human capital risk increases over the course of one's career, due partly to increased salary and partly to fewer years remaining to recover from setbacks, the individuals should shift their asset allocation from high-yielding equity instruments ('stocks') early on in their career, to safer, lower-yielding instruments as they age (Bodie et al. 2007). This reduces the overall volatility of their worth (being the sum of human capital and asset capital). This should result in a more certain final value for their retirement savings - as the lower-yielding instrument is associated with lower volatility.

Van Rooij, Lusardi and Alessie (2012) suggest that there is a relationship between financial literacy and the decision to invest in equities. Guiso, Sapienza and Zingales (2008) 
contend that those who are less financially literate distrust the equity market and are, therefore, less likely to invest in equities, and are less likely to diversify their asset holdings. This indicates that those who are less financially literate might be more inclined to accept an investment in a low-risk ${ }^{2}$ fund as a consequence of the human interaction they have with financial advisors.

Advances have been made to determine an individual's risk tolerance before constructing an investment portfolio. However, despite the use of these diagnostic tools, complete accuracy is not guaranteed. Using a sample of 386 financial advisors and 458 of their clients, Roszkowski and Grable (2005) found a weak positive correlation between the advisor's rating and the client's rating. Advisors were shown to assign too much diagnostic value to particular demographic variables when estimating their client's risk tolerance (Roszkowski \& Grable 2005). This risk tolerance stereotyping has been found in prior literature relating to gender perceptions, as discussed by Willows and West (2012).

Collectively, the behavioural influences on retirement savings behaviour are significant. It is possible to conclude that while an economic theory such as the life-cycle hypothesis may predict economic behaviour of a rational individual, the aforementioned behaviours show that individuals do not always act rationally, and are not always capable of maximising their own utility.

\section{Conclusion}

An analysis of Regulation 28 showed strong arguments to invest in Regulation 28 retirement funds, as these funds provide tax benefits and relatively simple investment vehicles for their members to save for retirement. However, it has been shown that regulation does not necessarily result in increased returns, and that the active management required can be detrimental to the investors involved (Basu \& Andrews 2014).

The alternative to investing in Regulation 28 funds is for an individual to make their own investment choices, discretionary investment, where the individual can choose their own asset allocation, and invest directly in the underlying instruments that a Regulation 28 fund would. This would result in a loss of the tax benefit, but would also not limit the underlying investments that an individual could select. The potential advantages of discretionary investments include higher returns, easily accessible capital and lower tax rates upon disposal ${ }^{3}$. The asset allocation restrictions imposed on Regulation 28 funds might result in suboptimal investments, which may result in members receiving significantly lower returns than if they were to invest in a discretionary manner.

2.Regulation 28 compliant funds are accepted to be lower-risk funds, as will be explained in the next section infra.

3.Certain discretionary investments are deemed to be capital in nature in terms of $\mathrm{s} 9 \mathrm{C}$ of the Income Tax Act, subject to a holding period of 3 years. Consequently, upon disposal any gains in value are taxed at a maximum effective rate of $13.653 \%$.
The literature also suggests that the life-cycle hypothesis (Modigliani \& Brumberg 1954) best explains savings behaviour. Furthermore, human beings do not always behave as economic models predict, due to inherent behavioural biases, which result in irrational behaviour.

\section{Research methods and design}

The literature reviewed has highlighted a contrast between the optimal manner in which individuals should save for retirement and the structure of Regulation 28 limits imposed on retirement funds in South Africa.

As a result, the research questions for this study are as follows:

- What is the differential nominal return that is required from discretionary, non-Regulation 28 compliant investments over a career in order to account for the tax incentives received by Regulation 28 compliant funds?

- Is the return differential between compliant and noncompliant funds feasible given the historical performance of the South African stock market?

- Is Regulation 28 an appropriate tool for managing investment risk, considering the correlation of Regulation 28 compliant fund returns with the Johannesburg Stock Exchange (JSE) and the variability of returns as measured by standard deviation?

\section{Study design}

The research was undertaken by constructing a hypothetical quantitative model ('the model') which contrasts the results of discretionary investment into an index tracking investment fund and investment in Regulation 28 compliant funds. For the purposes of this study, it is assumed that employers do not give employees the option to contribute to pension funds or provident funds. Rather, the Regulation 28 fund is assumed to be a retirement annuity fund.

The model is created with two hypothetical individuals. These individuals are identical in terms of earnings capability, health, career length and life expectancy. The first individual will save for retirement in a Regulation 28 compliant retirement annuity fund and will be termed the regulatory investor. The second individual, termed the discretionary investor, will save in a discretionary manner in assets that do not comply with Regulation 28 and will therefore forego the tax deduction of contributions to retirement savings. Both individuals' saving behaviour will follow that of the lifecycle hypothesis whereby they accumulate capital over their working career and then dis-save from retirement until death.

The effect of the South African tax legislation is that there is an incentive to save in a Regulation 28 compliant fund. The manner in which these incentives work is to moderately increase the size of the initial investment as a result of the tax relief they afford the individual (Attanasio \& Banks 2004). Refer to Appendix 1 and 2 for two illustrative examples. 
The model functions based on the input assumptions below. The regulatory investor contributes the maximum permissible $27.5 \%$ of their income to a Regulation 28 compliant fund each year, from their first working year until the year of retirement. During each of these years, the investor earns a nominal return on the balance of their retirement savings equal to that of their selected investment vehicle.

The model incorporates the tax liability of each hypothetical individual and is constructed in a manner such that the size of the contributions that are made by the discretionary investor are calculated, and will be less than those of the regulatory investor (i.e. the discretionary investor's contributions are 'after-tax'), so that both individuals have the same disposable income after settling their tax liabilities and contributing to their respective investments. The purpose of this is to ensure comparability of the standard of living of the two hypothetical individuals. An illustrative example is included in Appendix 2.

Upon retirement, both investors know with certainty that they will live a further 20 years, and therefore will draw down the maximum annuity possible that will ensure that their retirement savings last until death.

\section{Assumptions}

Given the nature of the model, it is necessary for a variety of input assumptions to be made. These are briefly discussed below.

\section{Career and life expectancy}

The individual will have a working (and saving) career of 40 years, and will live a further 20 years after retirement. The retirement age has been set at 65 years of age, this being the general retirement age in terms of South African generally accepted labour practice for formal employment.

\section{Earning capacity and taxation}

In the initial base case, the individual does not experience any real salary growth and begins their working career in the lowest tax bracket. This initial case is then modified several times by placing the individual at the beginning of their career in each of the current distinct tax brackets. This results in seven base cases. The tax brackets and annual rebates are assumed to grow with inflation such that the study eliminates the effect of 'bracket creep' or fiscal drag4. Based on the data provided, it is apparent that the South African Revenue Service (SARS) does not have a consistent basis for the changes to tax brackets and annual rebates; hence, a modicum of uncertainty exists within this particular variable, which would need to be addressed with further research.

The Taxation Laws Amendment Act (No. 31 of 2013) imposes a deduction cap of R350 000 on contributions. Any contributions above this R350 000 will not result in a tax deduction. This

\footnotetext{
4.'The process whereby an income tax structure with marginal rate progression generates revenue growth faster than income growth, due to individuals crossing
into higher marginal rate tax brackets if thresholds are adjusted at less than the rate into higher marginal rate tax brackets if thresholds are adjus
of increase of nominal incomes' (Creedy \& Gemmell 2014).
}

implies that the salary cap for contributing $27.5 \%$ of one's salary is R1 272727 in 2016. For the purposes of this study, it is assumed that the salary cap, and consequently the deduction cap, will also grow at the inflation rate. The comments above in regard to bracket creep are also apposite for this variable.

\section{Contributions and saving behaviour}

The regulatory investor will contribute the maximum deductible amount, being $27.5 \%$ of the retirement funding income, subject to the annual limit of R350 000, as per the Taxation Laws Amendment Act. The discretionary investor will contribute the amount that will result in his or her after-tax, post-contribution disposable income being equal to that of the regulatory investor.

\section{Inflation, investment timing and returns}

Inflation is assumed to be $6 \%$ per annum, the upper bound of the South African Reserve Banks inflationary target band (South African Reserve Bank 2015). The critical assumption is that investments will earn a consistent nominal annual return equal to the historic return on the selected investment vehicle - that being a Regulation 28 compliant fund for the regulatory investor and a JSE index tracking fund for the discretionary investor.

The discretionary investor is assumed to incur additional tax on $10 \%$ of his or her annual investment return ${ }^{5}$; a portion of this is likely to be in the form of dividends, which are subject to withholdings tax, thereby modifying his or her overall tax liability. Dividends withholding tax is levied at $15 \%$ on South African resident taxpayers in terms of s64 of the Income Tax Act. Historically, the dividend yield on the JSE All Share Index (JSE: ALSI) has been between 2.5\% and 3\% (Johannesburg Stock Exchange 2015). This equates to tax of approximately $0.045 \%$. Therefore, the $10 \%$ used is overly prudent and prejudices the discretionary investor, as it has the effect of overstating his or her tax liability and thus understating possible real investment returns. The additional tax is calculated using $10 \%$ of the annual investment return, multiplied by his applicable marginal tax rate.

Post retirement, and for the sake of making a direct comparison of the differential effect on wealth accumulation, both investors will annuitise their portfolios entirely and earn inflationary returns on their remaining investment such that additional wealth is not created in the years of retirement. As these savings are growing at inflation, there will not be any effect on tax, as the tax brackets have been assumed to move at inflationary rates too; consequently, no real wealth is created nor additional taxes paid in real terms. Succinctly put, both investors' real wealth measured as their entire retirement savings remains constant and is only diminished

5.Assume the investor has a savings balance of R100 000 and their marginal tax rate is $38 \%$. Assume further their selected investment vehicle earns $15 \%$ in the current year. Their pre-tax return would be R15 000 . Using the above restriction, $10 \%$ (R1 be paid, and only R14 430 would be accumulated to the savings balance.

6.A tax rate of $15 \%$ multiplied by the dividend yield of $3 \%$ results in an effective tax of $0.0045 \%$ on the total return in a given year. 
by their withdrawals ('drawdowns') over their remaining lifespan. A further simplifying assumption for the sake of making a direct comparison is that both investors will have accumulated sufficient capital in absolute terms to be at the same marginal tax rate.

\section{Retirement behaviour}

Upon retirement, neither investor will withdraw one-third of their investment. The new legislation in the Taxation Laws Amendment Act legislates that should an individual have more than R150 000 saved in a fund regulated by Regulation 28, two-thirds of these savings must be used to purchase an annuity, or be paid out as an annuity. Therefore, the amount remaining in the respective savings vehicle will be drawn down as an annuity over 20 years. This assumption is simplifying, in order to remove the complexity and variability of the amount that could be withdrawn. The individual is assumed to have no bequest motive and to know that they will live, with certainty, for exactly 20 years post retirement.

\section{Data analysis}

The nominal returns for Regulation 28 investments are based on the best performing of 14 compliant funds. The ranking of these funds was performed by Morningstar and Profile Data. The data for fund returns used in the model reflect a nominal return from October 1995 - October 2015. The best performing Regulation 28 compliant fund had returned an average nominal return of $18.49 \%$ per annum over the period.

The returns for discretionary investment are based upon indices of the JSE, over the same period ending in October 2015. The primary results will be based on the JSE: ALSI.

\section{Limitations}

This study does not take into account the transaction costs that would be involved in investing. As both Regulation 28 funds and discretionary investors would incur these on different scales, it is assumed that the difference in the fees charged to the discretionary and regulatory investors would be minimal.

Furthermore, the asset allocation of the discretionary investor is likely to change as that investor approaches retirement and begins to diversify his or her asset allocation to adjust to a lower overall risk profile. It is noteworthy that Regulation 28 attempts to mimic this posited behaviour by limiting the risk exposure of Regulation 28 compliant funds to attain a more moderate risk profile. The exact time point that this takes place will vary from investor to investor based on their individual risk appetite.

\section{Results}

In this section, each of the three research questions is presented with its corresponding results. Thereafter, the results are discussed.

\section{Research Question 1}

What is the differential nominal return that is required from discretionary, non-Regulation 28 compliant investments over a career in order to account for the tax incentives received by Regulation 28 compliant funds?

Table 1 displays the differential returns required by discretionary investment over the course of a career and reflects the answer to

TABLE 1: Differential return required.

\begin{tabular}{|c|c|c|c|c|c|c|c|c|}
\hline Scenario & Variable & 1 & 2 & 3 & 4 & 5 & 6 & 7 \\
\hline Description & - & Lowest tax bracket & 2nd bracket & 3rd bracket & 4th bracket & 5th bracket & Top bracket & Salary cap \\
\hline Starting annual salary & - & 150000 & 260000 & 380000 & 520000 & 680000 & 1000000 & 1300000 \\
\hline Percentage saving in Regulation 28 & - & $27.50 \%$ & $27.50 \%$ & $27.50 \%$ & $27.50 \%$ & $27.50 \%$ & $27.50 \%$ & $27.50 \%$ \\
\hline Inflation & - & $6 \%$ & $6 \%$ & $6 \%$ & $6 \%$ & $6 \%$ & $6 \%$ & $6 \%$ \\
\hline Real salary growth & - & $0 \%$ & $0 \%$ & $0 \%$ & $0 \%$ & $0 \%$ & $0 \%$ & $0 \%$ \\
\hline Length of career (years) & - & 40 & 40 & 40 & 40 & 40 & 40 & 40 \\
\hline Regulation 28 return (working career) & $A$ & $18.49 \%$ & $18.49 \%$ & $18.49 \%$ & $18.49 \%$ & $18.49 \%$ & $18.49 \%$ & $18.49 \%$ \\
\hline Post-retirement return & - & $6.01 \%$ & $6.01 \%$ & $6.01 \%$ & $6.01 \%$ & $6.01 \%$ & $6.01 \%$ & $6.01 \%$ \\
\hline Terminal salary & B & 1455526 & 2522912 & 3687333 & 5045824 & 6598385 & 9703507 & 12614560 \\
\hline Retirement savings value & C & 289588902 & 501954096 & 733625218 & 1003908193 & 1312803021 & 1930592678 & 2457119933 \\
\hline Retirement fund drawdown & $\mathrm{D}$ & 9429411 & 16076650 & 23328185 & 31788308 & 41457020 & 60794444 & 77275266 \\
\hline Discretionary investments & - & & & & & & & \\
\hline Required return of discretionary investment & $\mathrm{E}$ & $17.64 \%$ & $18.14 \%$ & $19.18 \%$ & $19.26 \%$ & $19.49 \%$ & $19.05 \%$ & $19 \%$ \\
\hline Discretionary saving value & $\mathrm{F}$ & 189853663 & 338566643 & 499849600 & 684066647 & 894715352 & 1315322414 & 1674072438 \\
\hline Discretionary fund draw down & G & 9429411 & 16076650 & 23328185 & 31788308 & 41457020 & 60794444 & 77275266 \\
\hline Difference (drawdown) & $D-G$ & 0.00 & 0.00 & 0.00 & 0.00 & 0.00 & 0.00 & 0.00 \\
\hline Difference in return & - & $-0.85 \%$ & $-0.34 \%$ & $0.69 \%$ & $0.78 \%$ & $1.00 \%$ & $0.56 \%$ & $0.56 \%$ \\
\hline
\end{tabular}

A, The annual nominal return earned by the Regulation 28 compliant fund each year over the course of the regulatory investor's career, $18.49 \%$ per annum; B, The terminal salary is the salary that the individual earned in the year immediately preceding retirement; $C$, The value (closing balance) of total regulatory retirement savings at the date of retirement. This is calculated using the opening balance of the savings, plus investment return for the annum, plus additional savings. This is performed annually until retirement, with the prior year's opening balance, plus investment returns and additional savings for the annum forming the current year's opening balance; D, The retirement fund draw down refers to the total amount that the regulatory investor can withdraw in their first year of retirement. This amount increases by inflation each year until retirement resulting in a zero balance at the end of the 20 years of retirement. The amount is calculated as a constant growing annuity with the starting value equal to that of variable D, the growth rate equal to inflation, the ending value equal to zero and the time period equal to 20 years; $E$, The variable representing the required nominal annual return required by the discretionary investment in order for the discretionary investor to be able to withdraw the same as the regulatory investor in retirement; $F$, The value (closing balance) of total discretionary retirement savings at the date of retirement. This is calculated using the opening balance of the savings, plus investment return for the annum, less taxes on the investment return plus additional savings. This is performed annually until retirement, with the prior year's opening balance, plus investment returns and additional savings for the annum forming the current year's opening balance; $\mathrm{G}$, The retirement fund draw down refers to the total amount that the discretionary investor can withdraw in their first year of retirement. This amount increases by inflation each year until retirement resulting in a zero balance at the end of the 20 years of retirement. The amount is calculated as a constant growing annuity with the starting value equal to that of variable $F$, the growth rate equal to inflation, the ending value equal to zero and the time period equal to 20 years. 
research question 1 . Table 1 only reflects the variation of one input variable, being the starting annual salary.

Table 1 shows that the additional nominal return required by a discretionary investor varies depending on the investor's particular tax bracket. The additional return varies from $-0.85 \%$ to a maximum of $1.00 \%$ per annum over the course of the individual's career.

What is apparent from Table 1 is that saving for retirement can be an effective vehicle to accumulate wealth. Any investment that is earning a return in excess of inflation is creating real wealth for the holder. Based on the input assumptions used in the model, either individual could be in a position where they would be able to withdraw approximately six times their final salary for each of the 20 years of retirement. This is not an aberration, as the purpose of the model is to calculate the differential return required by discretionary investment in order to be indifferent between regulatory investment and discretionary investment.

While saving to withdraw six times the final salary is essentially unrealistic, given the human behavioural pitfalls highlighted in the literature review, it does indicate a potential problem with the current proposals for retirement saving. By allowing an individual a tax deduction for contributions to a retirement fund during their working career, the legislation essentially defers taxation from the working career until retirement. For individuals in the lower tax brackets, this is punitive, as their retirement savings value results in a large increase in their disposable income at retirement, which results in the individual moving to higher tax brackets, resulting in these individuals paying more tax in retirement for behaving exactly as the legislation intended.

The largest additional nominal returns are required by discretionary investors in the fourth and fifth tax brackets. These investors are the ones who fiscal drag affects the most, with the greatest level of drag exhibited as they move from their respective tax brackets into the highest marginal tax bracket.

\section{Research Question 2}

Is this return differential feasible given the historical performance of the South African stock market?

The JSE: ALSI ('J203') was formed in June 2002. Consequently, the total return period available is limited to June 2002 to October 2015, a period of 13 years and 5 months. Data also exist for the Johannesburg Stock Exchange All Share Capped Index ${ }^{7}$ ('J303'), and the Johannesburg Stock Exchange Shareholder Weighted All Share Index ${ }^{8}$ ('J403').

7.The All Share Capped Index follows the same construction methodology as the ALS and only differs with regard to the capping of stock weightings to $10 \%$ per stock.

8.Shareholder Weighted (SWIX) indices have the same constituents as an existing market capitalisation weighted index. However, all constituents are weighted in the SWIX indices by applying an alternate free float, called the SWIX free float. The SWIX free float represents the proportion of a constituent's share capital that is held in free float represents the proportion of a constituent's share capital that is held in
dematerialised form and registered on the South African share register, maintained dematerialised form and registered on the South African share register,
by STRATE. The SWIX free float will not exceed the company free float.
When considering this 13-year period, the annual nominal return on the J203 is $16.23 \%$ per annum 9 . The best performing Regulation 28 compliant fund over the same time period returned $15.63 \%$ per annum. The J303 returned $16.76 \%$ per annum and the J403 returned $17.75 \%$ per annum over the same period.

Therefore, depending on the tax bracket that an individual is in, it is feasible for an individual to achieve annual returns that would make discretionary investment beneficial to them. This is the case for individuals in the first two tax brackets if the J203 is used, and all individuals if the J303 or J403 is used as the discretionary investment vehicle.

\section{Research Question 3}

Is Regulation 28 an appropriate tool for managing investment risk, considering the correlation of Regulation 28 compliant fund returns with the JSE and the variability of returns as measured by standard deviation?

The top three Regulation 28 compliant funds ('funds') over the period were compared to the JSE: ALSI. The comparison considered the mean annual return, the standard deviation and the correlation between movements in the monthly fund values and the JSE.

Table 2 shows that discretionary investment surpasses the investments of the three best performing Regulation 28 funds, as measured by mean annual return, whereas the results supra show the same on a compound annual growth basis. Table 2 further indicates that the standard deviation of the J203, and thus its return variability, is higher than those of the Regulation 28 compliant funds.

The purpose of Regulation 28 is to limit any particular fund's ability to make imprudent investment decisions (National Treasury 2011). It is shown in Table 3 that all three funds considered show low correlations to movements in the ALSI. This is a good indicator that the limits imposed by Regulation 28 are effective in limiting the exposure of the Regulation 28 compliant funds to equities. Table 3 indicates that while the Regulation 28 compliant funds have low return correlation to the J203, these funds' returns are highly correlated. This result may, prima facie, lead to the conclusion that these funds are exposed to the same or similar underlying investments. A finding that was prominent was that discretionary investors could accumulate between $65.5 \%$ and $68.2 \%$ of the retirement savings that a regulatory investor would require in order to have the same retirement savings withdrawals. This indicates that the additional taxes paid by regulatory investors in retirement account for approximately 30\% $35 \%$ of the total savings value at retirement. This can be attributed to the present value of additional tax in retirement outweighing the present value of the tax savings during the working career.

9.Based on a compound annual growth rate. 
TABLE 2: Mean returns and standard deviation

\begin{tabular}{lcccc}
\hline Measure & JSE J203 & Fund A & Fund B & Fund C \\
\hline Mean annual return & $19.589 \%$ & $17.610 \%$ & $16.539 \%$ & $15.892 \%$ \\
Standard deviation & $19.041 \%$ & $12.711 \%$ & $10.301 \%$ & $10.677 \%$ \\
\hline
\end{tabular}

Source: Johannesburg Stock Exchange, 2015, JSE ALSI Monthly Values, Monthly Market Statistics, viewed 25 October 2015, from http://www.jse.co.za/

JSE, Johannesburg Stock Exchange.

TABLE 3: Correlation.

\begin{tabular}{lcccc}
\hline Correlation & JSE J203 & Fund A & Fund B & Fund C \\
\hline JSE J203 & 1 & - & - & - \\
Fund A & 0.189184 & 1 & - & - \\
Fund B & 0.143246 & 0.874563 & 1 & - \\
Fund C & 0.199948 & 0.935405 & 0.864439 & 1 \\
\hline
\end{tabular}

JSE, Johannesburg Stock Exchange.

\section{Robustness check}

Sensitivity analyses were performed, using the same model as in Table 1, while all variables remained constant other than the return earned by a Regulation 28 compliant fund. The return was increased to a nominal return of $23 \%$ per annum and decreased to a nominal return of $13 \%$ per annum. The purpose was to test whether the differential return required by discretionary investors differs drastically based on the return earned by regulatory investors. The results showed that the differential returns required do not differ by a large quantum from the original results presented in Table 1.

\section{Conclusion and recommendations}

The findings of this study indicate that Regulation 28 may be effective at reducing the investment (and, indeed, behavioural) risk to which an individual's retirement savings are exposed. There is little doubt that Regulation 28 exists, at least in part, to protect investors (particularly those with a high propensity for risk) from themselves. However, this is not what this study sought to address.

Judged only by the return differential between compliant and non-compliant funds (which is the only factor being assessed in this study), the limits imposed by Regulation 28 may lead to suboptimal investment choices should individuals be motivated to reduce their current tax liability by investing in a Regulation 28 compliant fund. This imposition burdens those persons who most need retirement funding without an added tax liability occasioned by the deferred tax liability as discussed above. Further research is recommended to assess further outcomes when withdrawing post-retirement income and additional application on real examples.

The results of this study offer initial evidence that discretionary investment offers higher returns, which indicates that individuals should opt for discretionary investment. However, these results have not been riskadjusted. Accordingly, individuals should invest in order to address their investment goal, which may be solely to maximise retirement wealth, in which case discretionary investment is preferred. If investors seek to maximise retirement wealth while minimising possible variability in that wealth, then a Regulation 28 compliant fund may be the superior alternative.

\section{Acknowledgements Competing interests}

The authors declare that they have no financial or personal relationships that may have inappropriately influenced them in writing this article.

\section{Authors' contributions}

G.D.W. was a supervisor of the master's dissertation on which the article is based and was the primary author in conversion and re-work of the research into the article for journal publication. T.B. is the student who performed the research for the Master's dissertation. D.W. was a supervisor of the master's dissertation.

\section{References}

Attanasio, O.P. \& Banks, J., 2004, 'Effectiveness of tax incentives to boost (retirement) saving: Theoretical motivation and empirical evidence', The Institute for Fiscal Studies 4(33), 1-36, viewed October 2015, from http://discovery.ucl.ac.uk/ 2844/1/2844.pdf

Australian Taxation Office, 2017, Tax on contributions, viewed 02 March 2018, from https://www.ato.gov.au/individuals/super/super-and-tax/tax-on-contributions/

Basu, A. \& Andrews, S., 2014, 'Asset allocation policy, returns and expenses of superannuation funds: Recent evidence based on default options', Australian Economic Review 47(1), 63-77. https://doi.org/10.1111/1467-8462.12040

Behrman, J.R., Mitchell, O.S., Soo, C.K. \& Bravo, D., 2012, 'How financial literacy affects household wealth accumulation', American Economic Review 102(3), 300-304. https://doi.org/10.1016/j.micinf.2011.07.011.Innate

Benartzi, S. \& Thaler, R.H., 2013, 'Behavioral economics and the retirement savings crisis', Science Magazine 339, 1152-1153. https://doi.org/10.1126/science. 1231320

Bikker, J.A., Broeders, D.W., Hollanders, D.A. \& Ponds, E.H., 2012, 'Pension fund's assets allocation and participation age: A test of the life cycle model', The Journal of Risk and Insurance 79(3), 595-618. https://doi.org/10.1111/j.1539-6975. 2011.01435.x

Blanchett, D., Finke, M.S. \& Pfau, W.D., 2013, Optimal portfolios for the long run, viewed 25 October 2015, from http://ssrn.com/abstract=2320828

Bodie, Z. \& Treussard, J., 2007, 'Making investment choices as simple as possible, but not simpler', Financial Analysts Journal 63(3), 42-47. https://doi.org/10.2469/faj. v63.n3.4689

Bodie, Z., Treussard, J. \& Willen, P., 2007, 'The theory of life-cycle saving and investing', Public Policy Discussion Papers, Federal Reserve Bank of Boston 7(3), 1-28, viewed 06 December 2014, from http://www.econstor.eu/handle/10419/ 59251

Cocco, J.F., Gomes, F.J. \& Maenhout, P.J., 2005, 'Consumption and portfolio choice over the life cycle', Review of Financial Studies 18(2), 491-533. https://doi. over the life cycle, Reviev
org $/ 1093 / \mathrm{rfs} / \mathrm{hhi017}$

Creedy, J. \& Gemmell, N., 2014, 'Can automatic tax increases pay for the public spending effects of population ageing in New Zealand ?', New Zealand Economic Papers 48(2), 183-195. https://doi.org/10.1080/00779954.2013.874394

Dimson, E., Marsh, P., Staunton, M., Kersley, R. \& O'Sullivan, M., 2017, Globa Investment Returns Yearbook 2017, Credit Suisse, Zurich.

Donnelly, L., 2017, 'SA hits a century of good returns', Business - Mail\&Guardian, 09 March, viewed 02 March 2018, from https://mg.co.za/article/2017-03-09-00sa-hits-a-century-of-good-returns

Fernández-Villaverde, J. \& Krueger, D., 2011, 'Consumption and saving over the life cycle: How important are consumer durables?', Macroeconomic Dynamics 15(5), 725-770. https://doi.org/10.1017/S1365100510000180

Fidelity Investments, 2017, Quick-Start Guide to Your 401(k), viewed 02 March 2018, from https://www.fidelity.com/viewpoints/financial-basics/guide-to-401k

Friedman, M., 1957, 'The permanent income hypothesis', in A theory of the consumption function, pp. 20-37, viewed October 2015, from http://www.nber. org/books/frie57-1

Guiso, L., Sapienza, P. \& Zingales, L., 2008, 'Trusting the stock market', The Journal of Finance 63(6), 2557-2600. https://doi.org/10.1111/j.1540-6261.2008.01408.x

Internal Revenue Service, 2017, 401k Plan Overview, viewed 02 March 2018, from https://www.irs.gov/retirement-plans/plan-participant-employee/401kresource-guide-plan-participants-401k-plan-overview

Johannesburg Stock Exchange, 2015, JSE ALSI Monthly Values, Monthly Market Statistics, viewed 25 October 2015, from http://www.jse.co.za/ 
Keynes, J.M., 1936, The general theory of employment, interest and money, Palgrave Macmillan, Basingstoke.

Klapper, L., Lusardi, A. \& Van Oudheusen, P., 2015, Financial literacy around the World: Insights from the Standard \& Poor's ratings services global financial literacy survey.

Knoll, M.A.Z., 2010, 'The role of behavioral economics and behavioral decision making in Americans' retirement savings decisions', Social Security Bulletin 70(4). 1-23.

Lusardi, A. \& Mitchell, O.S., 2014, 'The economic importance of financial literacy : Theory and evidence', Journal of Economic Literature 52(1), 5-44. https://doi. org/10.1257/jel.52.1.5

Luüs, C., 2015, 'Long term real investment returns', Financial Markets Journal viewed 02 March 2018, from https://financialmarketsjournal.co.za/long-term-realinvestment-returns/

Mehra, R., 2003, 'The equity premium: Why is it a puzzle?', National Bureau of Economic Research Working Paper Series 9512(1), 54-69. https://doi.org/10.3386/w9512

Miller, G., 2011, 'Impact of the financial crisis on retirement security', Huffpost, viewed 02 March 2018, from https://www.huffingtonpost.com/rep-georgemiller/impact-of-the-financial-c b 132629.html

Modigliani, F. \& Brumberg, R., 1954, 'Utility analysis and the consumption function: An interpretation of cross-section data', in Post Keynesian Economics, Rutger University Press, New Brunswick, NJ.

National Treasury, 2011, 'Pension Funds Act (24/1956): Amendment of Regulation 28 of the Regulations made under section 36', Government Gazette 549(34070), 1-36.

Pfau, W.D., 2010, 'Lifecycle funds and wealth accumulation for retirement: Evidence for a more conservative asset allocation as retirement approaches', Financial Services Review 19, 59-74. viewed March 2015, from http://content.ebscohost. com.library3.webster.edu/ContentServer.asp? T $=P \& P=A N \& K=49743351 \& S=R \& D$ f5h\&EbscoContent=dGJyMNHX8kSeqLM4xNvgOLCmrOqep7NSsae4SrWWxWXS\& ContentCustomer=dGJyMPGut1G1qLdKuePfgeyx44Dt6flA\%5Cnhttp://library3. webster.edu/login?url=http://sear

Ratner, M. \& Leal, R.P.C., 2005, 'Sector integration and the benefits of global diversification', Multinational Finance Journal 9(3), 235-267. https://doi.org/ 10.17578/9-3/4-5
Roszkowski, M.J. \& Grable, J., 2005, 'Estimating risk tolerance: The degree of accuracy and the paramorphic representations of the estimate', Financial Counseling and Planning 16(2), 29-47, viewed March 2015, from https://www.afcpe.org/ and Planning 16(2), 29
assets/pdf/vol1624.pd

Skinner, J., 2007, 'Are you sure you're saving enough for retirement?', Journal of Economic Perspectives 21(3), 59-80. https://doi.org/10.1257/jep.21.3.59

Somaguda-Nogantshi, A., 2008, South Africa's retirement reform: Lessons from the Chilean Reform enacted in 1981, University of Pretoria, Pretoria.

South African Reserve Bank, 2015, Inflation targeting framework, viewed 09 Augus 2015, from https://www.resbank.co.za/MonetaryPolicy/DecisionMaking/Pages/ default.aspx

Thaler, R. \& Benartzi, S., 2007, 'The behavioral economics of retirement savings behavior', AARP Public Policy Institute (January), viewed 09 September 2014, from http://assets.aarp.org/rgcenter/econ/2007_02_savings.pdf

Van Rooij, M. Lusardi, A. \& Alessie, R.J.M, 2012, 'Financial literacy, retirement planning, and household wealth', The Economic Journal 122, 449-478. https:// doi.org/10.1016/j.joep.2011.02.004

Van Zyl, N. \& Van Zyl, D., 2014, 'The impact of behavioural economics and finance on retirement provision', in Actuarial Society of South Africa 2014 Convention, Cape Town, pp. 694-727.

Wachter, J.A., 2010, 'Asset allocation', Annual Review of Financial Economics 2(1) 175-206. https://doi.org/10.1146/annurev-financial-073009-104026

Wepener, C.W., 2014, Optimal asset allocation for retirement funds: A South African perspective, University of Cape Town, Cape Town.

Willows, G.D., 2015, 'Missing persons from the population of unit trust investors', Proceedings of SAAA Conference 2015, International Association for Accounting Education \& Research (IAAER), East London, South Africa, 29 June - 1 July 2015, n.p.

Willows, G. \& West, D., 2012, 'Differential investment performance based on gender : A review of literature', in SAAA Western Cape Regional Conference: Peer-reviewed conference proceedings, Southern African Accounting Association, Cape Town, Western Cape, South Africa, September 2012, pp. 72-95. 


\section{Appendix 1}

\section{Reduced tax liability example}

Persons $A$ and $B$ are hypothetical identical individuals. Both have a pre-tax income of R1 000000 per annum. A opts to contribute $27.5 \%$ of his pre-tax salary to a Regulation 28 compliant pension fund. Person B opts to invest $27.5 \%$ of his pre-tax salary in local equities. The effect of this is that person $A$ will receive a deduction against their total income, whereas person $B$ will not. The result is that person $B$ will have less disposable income at year-end.

Assume further that the local equities have a nominal return 15\% per annum, whereas the Regulation 28 fund only earns a $10 \%$ return in the same year. For the sake of this illustration, we assume that the investment was made at the beginning of the financial year for both parties. Both parties are in the same income tax bracket - thus they are taxed R208 $587+40 \%$ of any amount exceeding R701 300 per the 2015/2016 tax regulations.

At year-end we compare total assets assuming that tax has been paid in full. The result is that person A has higher total assets, primarily as a result of having to pay less tax (see Table 1-A1).

TABLE 1-A1: Reduced tax liability example.

\begin{tabular}{llll}
\hline Variable & Calculation & Person A & Person B \\
\hline Pre-tax salary & A & R1 000 000.00 & R1 000 000.00 \\
Savings & B & $27.5 \%$ & $27.5 \%$ \\
Permissible deductions & $\mathrm{A} \times \mathrm{B}=\mathrm{C}$ & $\mathrm{R} 275000.00$ & - \\
Taxable income & $\mathrm{A}-\mathrm{C}=\mathrm{D}$ & $\mathrm{R} 725000.00$ & $\mathrm{R} 1000000.00$ \\
Tax liability & $\mathrm{E}$ & $\mathrm{R} 215304.00$ & $\mathrm{R} 328054.00$ \\
Disposable income & $\mathrm{D}-\mathrm{E}=\mathrm{F}$ & $\mathrm{R} 509696.00$ & $\mathrm{R} 396946.00$ \\
Total investment made & $\mathrm{G}=\mathrm{A} \times \mathrm{B}$ & $\mathrm{R} 275000.00$ & $\mathrm{R} 275000.00$ \\
Annual return & $\mathrm{H}$ & $10 \%$ & $15 \%$ \\
Year-end investments & $\mathrm{J}=\mathrm{G} \times(1+\mathrm{H})$ & $\mathrm{R} 302500.00$ & $\mathrm{R} 316250.00$ \\
Total assets (disposable & $\mathrm{F}+\mathrm{J}$ & $\mathrm{R} 812196.00$ & $\mathrm{R} 713196.00$ \\
income + investments) & & & \\
Total difference & - & R99 000.00 & - \\
\hline
\end{tabular}

\section{Calculation $\mathbf{E}$}

For taxable income of R701 300 and above, tax is charged at R208 $587+41 \%$ of the amount above R701 300 (South African Revenue Service, 2015). Therefore:

- Person A = R208 $587+[$ R23 $700 \times 41 \%]=$ R215 304

- $\quad$ Person $B=R 208587+[R 298700 \times 41 \%]=$ R328 054

\section{Appendix 2}

\section{Increased contribution example}

Assume the facts are the same as in example one, except that investor B reduces his investment amount such that they and investor $A$ have the same after-tax disposable income (see Table 1-A2).

TABLE 1-A2: Increased contribution example.

\begin{tabular}{llll}
\hline Variable & & Person A & Person B \\
\hline Pre-tax salary & A & R1 000 000.00 & R1 000 000.00 \\
Savings & B & $27.5 \%$ & $16.2 \%$ \\
Permissible deductions & $\mathrm{A} \times \mathrm{B}=\mathrm{C}$ & $\mathrm{R} 275000.00$ & - \\
Taxable income & $\mathrm{A}-\mathrm{C}=\mathrm{D}$ & $\mathrm{R} 725000.00$ & $\mathrm{R} 1000000.00$ \\
Tax liability & $\mathrm{E}$ & $\mathrm{R} 215304.00$ & R328 054.00 \\
Disposable income & $\mathrm{D}-\mathrm{E}=\mathrm{F}$ & $\mathrm{R} 509696.00$ & $\mathrm{R} 509696.00$ \\
Total investment made & $\mathrm{G}=\mathrm{A} \times \mathrm{B}$ & $\mathrm{R} 275000.00$ & $\mathrm{R} 162250.00$ \\
Annual return & $\mathrm{H}$ & $10 \%$ & $15 \%$ \\
Year-end investments & $\mathrm{J}=\mathrm{G} \times(1+\mathrm{H})$ & $\mathrm{R} 302500.00$ & $\mathrm{R} 186587.50$ \\
Total assets (disposable & $\mathrm{F}+\mathrm{J}$ & $\mathrm{R} 812196.00$ & $\mathrm{R} 696283.50$ \\
income) + investments & & & \\
Total difference & - & R115 912.50 & - \\
\hline
\end{tabular}

